\title{
Lessons from the Experiences of Currency Crisis, Focused on the Cases of Korea, Argentina, Mexico and Greece
}

\author{
Yongshik Choe, Hyun-jung Kim* \\ Email address: \\ ecnms21@hanmail.net (Yongshik C.),hjkim@assist.ac.kr (Hyun-jung K.) \\ ${ }^{*}$ Corresponding author
}

Seoul Business School, Seoul School of Integrated Sciences and Technologies (aSSIST), Seoul, South Korea

To cite this article:

Yongshik Choe, Hyun-jung Kim. Lessons from the Experiences of Currency Crisis, Focused on the Cases of Korea, Argentina, Mexico and Greece. International Journal of Business and Economics Research. Vol. 9, No. 4, 2020, pp. 192-201. doi: 10.11648/j.ijber.20200904.15

Received: May 3, 2020; Accepted: June 15, 2020; Published: June 28, 2020

\begin{abstract}
The currency crisis has happened intermittently in many countries around the world despite numerous studies about it. It might be its reason that the root cause of currency crisis is not clarified clearly yet. The causes well-known are not the root but the phenomena appeared in its developing process. If the root is clarified, the crisis would be prevented in advance. Above all, its resulting economic performance varies greatly from country to country and from time to time, of which reason is due to the differences in economic policies responding to the currency crisis. It is very important to overcome the currency crisis as well to prevent its occurrence because it damages any national economy very much causing economic hardships of its people. In order to prevent and overcome it, it is necessary to investigate its root cause and developing process. And the empirical experiences of the crisis are useful to clarify them. This paper investigates its root cause, economic principle and policy measures to overcome it through case study. In short, the currency crisis has been caused by the economic overheat, leading to a huge deficit of international payment, which has resulted in the soar of exchange rate, causing the depletion of international reserve because of the exchange rate loss which led the capital outflows. And some representative cases of currency crisis are helpful to establish and enact the policy measures to overcome it. If this principle and some cases of the crisis is understood well, it would be possible for any countries, especially for developing countries, to prevent in advance and overcome successfully it. This paper would contribute to the stable growths of developing countries because the root cause of currency crisis, its economic principle, and the policy measures to overcome it are clarified enough.
\end{abstract}

Keywords: Currency Crisis, Deficit of International Payment, Depletion of International Reserve, Economic Overheat, Twin Crises

\section{Introduction}

Many developing countries have experienced intermittently currency crisis several times and suffered economic hardships caused by it every time. And the crisis of a country has been contagious as it has spread to other countries soon. Even todays it often happens in the world economy, especially in the developing countries such as Brazil, Argentina, Turkey, Venezuela, Uzbekistan and South Africa in the mid-2010s, and Brazil in 2020 due to the Covid19 despite that many researches have been accomplished and that even alarming indicators against the crisis are suggested by some economists, as will be seen shortly. So, it is still important to investigate it further for the countries which are likely to confront it in near future.
The case study of currency crises would help the governments of developing countries understand the economic principle why currency crisis occurs, how it develops, and what consequences it leaves to the economy. And if this economic principle is understood clearly, the governments would find a way to prevent the crisis. Even if they do not prevent the crisis, successful cases would indicate them what policy should be enacted to overcome it effectively. Even a failure case would help them understand how to deal with its tragic consequences.

This paper is organized as follows; first section is the introduction as above; second section deals with the theoretical considerations on the crisis; third section examines past experiences of either success and failure ones such as the crises of Korea in 1998, Argentina in the 1980s, 
Mexico in 1982 and 1995, and Greece in the 2010s; and last section concludes this paper, summarizing main achievements and proposing future works.

\section{Theoretical Considerations}

In general, currency crisis is included into financial crisis. This general perception would have been widespread since the former used to be accompanied by the later. The former and the latter are often referred to twin crises [1]. Currency crisis is even called as financial crisis. Thus, studies on the latter cover usually the former. And various studies have been conducted on the latter, which are so many not to be countable. Among them, [Manias, Panics, and Crashes] is noticeable [2]. According to the research, a fervent investment in stock or real estate market creates Manias resulting in a bubble, and Panics appear when the bubble breaks out, followed by Crashes of financial market.

Even the alarming indicators against financial and currency crises have been studied. In short, the alarming indicators consist of prices jump in stock and housing, plunge of their prices, bubble burst, decline in national creditability, worsening in international trade conditions, external debt, current account deficit of international payment, sharp rise of interest rate, and surge of exchange rate [3-15]. However, these studies have remained at the level which is unable to capture the crisis in advance or predict it as its theoretical basis, why and how these economic variables operate as the alarming indicators against the crisis, is insufficient yet. The crisis has occurred several times despite the development of alarming indicators, which reveals decisively their limitations.

In addition, international efforts have been made to prevent the financial crisis. Typically, the Bank for International Settlement (BIS) signed the BASEL I with some countries in 1988 which encouraged financial firms to maintain a certain ratio of equity capital. As the crisis often occurred despite the above agreement, the BASEL II was enforced in 2004, and the BASEL III was tightened in 2013 to strengthen the market regulations after the global financial crisis in 2008 became severe. Will the financial crisis occur no longer since the financial regulatory standards have been strengthened as above? As seen from the fact that the agreement has been renewed two times, the crisis is unlikely to be prevented despite the third agreement. Though many studies are conducted with the strengthened regulation enacting as above, financial and currency crises have occurred intermittently. And the crises have devastated particularly the developing countries. Therefore, preventing and overcoming the crises are one of the most important issues in developing countries.

By the way, the root causes of financial crisis and currency crisis are different from each other even if their developing processes are similar to each other. The former is caused by bubble collapse in financial market [2], while the latter has been occurred by the depletion of international reserve as well by the rapid expansion of domestic credit $[16,17]$. And the depletion of international reserve is usually caused by the current account deficit of which root is the economic overheat though it is not investigated enough yet. So, the case study of the crisis is still important, especially for developing countries to prevent it and to minimize its damages.

\section{Representative Cases of Currency Crisis in Developing Countries}

Many countries, especially developing countries, have confronted the currency crisis several times and suffered economic hardships every time. Among them, the worst case was the crisis of Argentina in the 1980s, the best overcoming case was that of Korea in 1998, while Mexico experienced a good practice as well a bad one during a short period of time. These cases provide valuable lessons for the developing countries that would face a currency crisis in near future. It is also needed to look closely at the Greek case in the 2010s which has lasted for years due to the confusion of terms as will be seen later.

\subsection{The Best Overcoming Case; The Currency Crisis of Korea in 1998}

Various analyzers have been made on the cause of Korean currency crisis in 1998. Some economists argued that the fundamentals of Korean economy were good at that time and only a temporal liquidity crisis occurred $[18,19]$. It is also argued that Korean economy was infected by the Thai currency crisis and the Korean crisis would not have happened if the Thai crisis did not burst $[20,21]$. Other economists pointed out the vulnerability of its banking and exchange rate systems which were controlled by the government [22-25]. The problem of corporate governance was also indicated as its cause [26-29]. And the deregulation of financial industry was pointed out for it too [30]. But all of them are the phenomena that appeared in its developing process. An inevitable cause of the crisis was already in progress as will be seen shortly.

The most serious problem is the fact that the general evaluation on the Korean overcoming against the crisis is incorrect or insufficient. Almost economists in Korea consider the case as a big failure despite that it is the most successful in the world history, of which issue will be discussed soon. What does it mean that almost economists misunderstand the Korean achievement despite that there has been no case to overcome more successfully it than Korea in word history? If a successful policy turns out to be a failure one, this successful policy will be neglected, and the policy to be failed will be adopted eventually. So, understanding correctly the policy to overcome it is more important than anything else for the future of the economy. The policy at the time should be evaluated so much that it shall be passed down to descendants. It is an intellectual property to be taught to many countries in risk of currency crisis. If the successful policy is widely known, a catastrophic blow to the economy would be avoided in developing countries even if they confront it. 


\subsubsection{Direct Cause; Depleting of Foreign Exchange Reserves}

In the simplest terms, the Korean crisis was caused by the depletion of its foreign exchange reserve. So, its direct cause can be identified easily when its depletion cause is revealed. In fact, the crisis was already prepared because the current account deficit amounted to $\$ 43.6$ billion during the four years just before the crisis, which was nearly double of its foreign exchange reserve in the mid-1990s. So, almost the reserve was depleting to cause the crisis. Although it was true that the deficit dropped to $\$ 8.2$ billion in 1997 from $\$ 23.0$ billion in 1996, it was essential to take in account that the economy declined rapidly. If the economy would have recovered, the deficit would have grown fast again. The economic downturn postponed the crisis for a while. Of course, the Kim Young-Sam regime (Feb 1993 - Feb 1998) introduced foreign debts to prevent its depletion. Foreign debts of Korea quadrupled to \$174 billion in 1997 from \$40 billion in 1993, with the annual average increase rate surpassing 40 percent. This snowballing foreign debts accelerated the crisis, with its exchange rate soaring. Even if the crisis would not have broken out in the Southeast Asia, Korea would have confronted it someday, and its economic impact would have become greater than ever.

Its root cause would be found easily if the reason why the deficit of current account increased so much as above was found. What was the reason? The deficit was rightly caused by the increase of its import. Its import grew faster than its export, leading to the deficit. The increase rate of import was 5.3 percent point higher than that of export in 1994, 1.7 percent points higher in 1995, and the gap widened to 7.6 percent point in 1996. Therefore, the root is found if the reason for the sudden increase of its import is investigated.

\subsubsection{The Root of Current Account Deficit; Overheated Economy}

Why did its import increase more than its export? The most decisive reason was the fact that its aggregate consumption became bigger than its aggregate production. Why did it happen? It is common that import increases more than export when the economy is overheated by the government's stimulating policy. In 1993, when the Kim Young-Sam regime was launched, its economic growth rate was 5.5 percent, its import increase was less than its export increase, and its current account was surplus. Afterwards its growth rate increased to 8.3 percent in 1994 and 8.9 percent in 1995. From the time on, its import increased greater than its export, and its current account deficit was snowballing. The growth rates over $8 \%$ were much higher than its growth potential at that time, which overheated the economy. In general, prices inflation used to happen when the economy was overheated. On the other hand, the import used to increase first when the domestic market was opened to abroad more and more. At that time, the Kim Young-Sam regime opened actively the domestic market with the propaganda of Globalization. So, cheap imports flowed into Korea to stabilize the prices. However, it played a crucial role in worsening the balance of international payment.

If its growth potential sustained high, there would have been no overheating and no large deficit of current account. In the late 1980s, its growth rate had surpassed $11 \%$ annually for three years, and its current account had posted a large surplus every year. At that time, its growth potential had stood with such high growth rates. However, since the late 1980 s, its growth potential had fallen fast. What was the reason? It was the enlargement of public sector. In the reality, the growth potential decreases when the public sector increases faster than the private sector because the expenditure of the former is spent in the field where the latter neglects because of low productivity. So, the national productivity declines when the former grows faster than the latter since the average productivity of the economy declines.

How big did the public sector grow? During 10 years from 1987 to 1996 when the economy was deteriorating, its fiscal expenditure increased about 4.8 times, compared with about 3.5 times that of ordinary GDP. Furthermore, policymakers had mobilized all means to conceal the fiscal expansion by creating some special accounts and new funds, which distorted the fiscal structure causing its inefficiency, inelasticity and inequity. Special accounts increased by 9.2 times and the asset of public funds increased by 6.3 times while the general account increased by 4.3 times during the years. The worst was the government affiliates. The total amount of their budgets increased by 24 times during 16 years from 1980 to 1996 while GDP grew by 10.6 times.

\subsubsection{Direct Cause of Economic Overheat; Currency Issuance and Fiscal Spending}

The economy was overheated during the Kim Young-Sam regime as seen above. Even in 1996, the current account deficit reached a record-high of $\$ 23.1$ billion despite the decreasing growth rate from 8.9 percent to 6.8 percent. What caused the economic overheating? Its first cause was the monetary expansion. The increase rate of currency issuance reached 41.6 percent at the end of 1993, while its usual increase rate had been around 10 percent in previous years. This currency evaporation overheated the economy. Despite the big increase of currency issuance, the economy showed signs of declining from the second half of 1995. So, the regime established newly the Management Fund of Public Funds in order to finance the government budget, with the increase rate of fiscal expenditure reaching 42.5 percent in 1995. As a result, the fiscal expanding rate was close to four times of its ordinary economic growth rate. Even in 1996 when the worst deficit of international payment was recorded, the rate of fiscal expansion reached 17.8 percent. This fiscal expansion caused its excess demand and increased greatly its import, which led to the worsening of its international payment balance.

\subsubsection{Trigger to Cause the Crisis; the Hanbo's Collapse}

Korea also experienced a typical financial crisis as other countries did. The bankruptcy of the Hanbo group, a conglomerate, triggered the financial crisis in early 1997. So, it is necessary to examine its process because the money 
amount had been abundant in the financial market only one year before the bankruptcy. This abundant money had gone to the stock market raising the stock index from 500 to 900 for two years, and the real estate market had been also bullish. However, in early 2007, the money dried out. Where did the abundant money go? In short, money also destroys credit as it creates credit. It is natural that credit destruction happens in the economy as credit creation does. The credit destruction worked in early 1997 when the Hanbo group went bankrupt.

Its bankruptcy was not restricted to the collapse of a chaebol. Hanbo leaved bad debts of 6.4 trillion won to the financial institutions. Its bad debts put pressure on them to raise their reserves for the loan loss and to lower their equity ratio, which made them recover existing loans and investments besides additional loans and new investments. This pressure caused a vicious cycle of credit destruction. The narrow money (M1) decreased by -11.4 percent at the end of 1997 while the currency decreased only by -0.7 percent. So, the interest rates of commercial banks rose to over 15 percent and corporate bonds became difficult to be repaid. As a result, small and middle companies went bankrupt by more than 30 thousand and even the chaebols such as Sammi, Dainong, Jinro, Haitai, Nasan, Hanshin, and Kia collapsed.

\subsubsection{Another Cause; Exchange Rate Did Not Work in Time}

As the balance of international payment continued to deteriorate, the exchange rate should have acted as a controller, but it did not at all. For example, when the current account deficit soared to more than $\$ 8.5$ billion in 1995 from $\$ 3.9$ billion in 1994, its exchange rate rather fell from 804 won to 771 won per dollar. In 1996, when the deficit increased to $\$ 23$ billion of record high, the rate remained 805 won almost same as to 1994 . The factor that its exchange rate did not play the role to reflect the international payment balance was one of the causes, so it is necessary to examine what hindered the rising of exchange rate.

Until the early 1990s, the Merchant Banks were called as the 'goose that lays golden eggs' in Korea since they borrowed money in foreign market at a low interest rate and loaned at a high interest rate in the domestic market, besides the foreign exchange gain. Many merchant banks were licensed by the regime for some rewards, increasing the number from six to thirty. The regime was born with the fate to defend the exchange rate because merchant banks should suffer the loss of exchange rate when it rose. For reference, most new merchant banks located in the president Kim's homeland.

Table 1. Major Economic Indicators of Korea in 1993-1997 (\$Billion, \%).

\begin{tabular}{llllll}
\hline Years & $\mathbf{1 9 9 3}$ & $\mathbf{1 9 9 4}$ & $\mathbf{1 9 9 5}$ & $\mathbf{1 9 9 6}$ & $\mathbf{1 9 9 7}$ \\
\hline Current Account & 0.9 & -3.9 & -8.5 & -23.0 & -8.2 \\
Foreign Debts & 43.9 & 56.9 & 78.4 & 104.7 & 174.2 \\
Growth Rate & 5.5 & 8.3 & 8.9 & 6.8 & 5.0 \\
Import Increase Rate & 2.5 & 22.1 & 32.0 & 11.3 & -3.8 \\
Exchange Rate (won/\$) & 808 & 789 & 775 & 844 & 1,415 \\
Currency Increase Rate & 41.6 & 8.7 & 14.8 & 3.4 & -0.7 \\
Fiscal Increase Rate & 12.6 & -0.2 & 42.5 & 17.8 & 7.9 \\
\hline
\end{tabular}

Source: Monthly Statistical Bulletin Dec. 2000, The Bank of Korea

\subsubsection{The Process of Successful Overcome Against the Currency Crisis}

In Korea 1998, 1.1 million workers were laid off and streets were full of the homeless, which was the result of the growth of -5.5 percent at the year. Many economists, even world-renowned economists, argued that this tragedy was caused by the harsh austerity policy that the IMF imposed on the Korean economy [16]. [18, 31, 32]. However, the Korean economy overcame the crisis for the shortest period and the sequelae were the least in world history. Rather the sharp recession in 1998 contributed to the successful overcome against it. What economic principles worked for its success? Overcoming the crisis should include two things; the one is to get out of the exhaustion of international reserve, and the other is to get out of the economic recession.

First, it was urgent to recover the reserve in order to escape the crisis. If the reserve was exhausted, its national economy went bankrupt. Thus, any country in currency crisis must obtain the bailout from IMF, and the bailout must be repaid someday. In order to repay it, the international payment balance must turn to surplus. So, it was essential to decrease the domestic demand with an austerity policy because it was difficult to increase its export as overseas markets were untouchable for its government. The Korean economy declined sharply in 1998, with the growth rate reaching -5.5 percent as seen already. It led to a rapid decrease in its import, resulting in the current account surplus of $\$ 40.4$ billion in the year. This massive surplus reduced the planned bailout of $\$ 58.5$ billion to $\$ 18.9$ billion. Most notably, its international reserve surpassed $\$ 52$ billion in end 1998 just a year after the crisis, nearly doubled to the highest level in the past. So, the Korean economy escaped from the depletion of its foreign exchange reserve and made a decisive momentum to overcome the crisis.

The remaining question was how the economy revived in a short time. Indeed, the reason why Korea's overcoming against the crisis should be highly evaluated was the fact that it entered a high-growth road in just one year after the crisis. Its growth rate reached 11.3 percent in 1999 and 8.9 percent in 2000. In order to overcome the crisis successfully that would come back in the future, it is necessary to reveal how this miracle was made. As there is no company that increases voluntarily its production, investment and employment unless its profit increases, it was urgent to increase profits of companies to revive them. Meanwhile, companies yield large profits only when the supplier's market is created because buyers come first, reducing the costs of transportation, sales, advertising and inventory.

The supplier's market happens when the aggregate supply falls faster than the aggregate demand though it is created in general when the economy is strong. The growth rate of -5.5 percent in 1998 played a role to create the supplier's market by collapsing many suppliers. If the government would not have adopted tightening policies, the crisis would have lasted for years like the countries of Latin America in the 1980s. If the recession lasted for years to cause the lack of demand, the demander's market would have lasted, which would have 
deteriorated the business balances of companies. Then the economy would have declined further, and more companies would eventually have gone bankrupt than ever.

\subsection{The Worst Case; The Currency Crisis of Argentina in the 1980s}

Argentina faced the currency crisis in end 1980, resulting in severe economic hardships. The growth rate was -5.7 percent in 1981 and -3.1 percent in 1982. This crisis was known to be caused by the oil shock, but it had conceived during the late 1970s. The biggest problem was the excessive increase in its fiscal expenditure to escape the economic slowdown in the late 1970s. Its fiscal deficit continued to increase to 6.7 percent of GDP in 1981. So, the consumer prices rose already by 444 percent in 1976, dropped slightly as the economy downed, and surpassed still 170 percent since
1977.

This explosive inflation undermined its international competitiveness. The current account turned to deficit since 1979, reaching \$4.8 billion in 1980 and \$4.7 billion in 1981 . In end 1980, the exhausting crisis of international reserve broke out. In addition, the base interest rate of the Fed in USA soared to 21.5 percent and the dollar value increased significantly. The interest payment on foreign debt of Argentina increased more than 10 times from 1981 to the middle of 1982. So, the currency crisis developed further. Its overcome should have been a priority, but its government increased its fiscal expenditure, increasing its deficit to 8 percent of GDP in 1983. This fiscal expansion caused the excessive demand, which made prices explosive and worsened the international payment balance.

Table 2. Argentina's Main Economic Indicators in 1978- 1987 (\%, \$billion).

\begin{tabular}{|c|c|c|c|c|c|c|c|c|c|c|}
\hline Year & 1978 & 1979 & 1980 & 1981 & 1982 & 1983 & 1984 & 1985 & 1986 & 1987 \\
\hline Growth Rate & -3.3 & 7.3 & 1.5 & -5.7 & -3.1 & 3.7 & 1.8 & -6.6 & 7.3 & 2.6 \\
\hline Prices Rate & 175.5 & 159.3 & 100.8 & 104.5 & 164.8 & 343.8 & 626.7 & 672.1 & 90.1 & 131.3 \\
\hline Current Acc. & 1.2 & -0.5 & -4.8 & -4.7 & -2.4 & -2.4 & -2.5 & -1.0 & -2.9 & -4.2 \\
\hline
\end{tabular}

Source; International Financial Statistics 1995, IMF

In 1983, Raul Alfonsin took office through a democratic election after the military regime resigned as the crisis worsened day by day. Unfortunately, its price inflation rate rose to 344 percent at that time. As a result, its industrial production decreased by -20 percent in 1983 , and the devaluation of Peso and bank-runs plunged the public into an extreme fear. In 1984, the inflation rate of nearly 600 percent threatened its economy to crash. Bernardo Grinspun was appointed as the Minister of Economy. He believed that the stimulus policy to increase fiscal spending, rather than the tightening policy, was the shortcut to its economic recovery. He claimed that imposing additional taxes on consumer goods would raise funds to repay foreign debts, with wages and prices freezing. In June 1984, creditors extended the maturity of foreign debts to August 14 which had to be repaid by March 30 and gave new loans of $\$ 125$ million. In end 1984, however, Grinspun's program lost power. The inflation jumped by more than 30 percent each month, and the economic recession became severe. In May 1985, IMF and creditors suspended all new loans and claimed its government to clarify the debt repayment schedule. Grinspun resigned [33].

The newly appointed minister, Juan Sourrouille, introduced a new currency in June 1985, named Austral. The economy took breath as the inflation rate fell to 3\% in August. In the fourth quarter of that year, the fiscal deficit fell to 2.2 percent of GDP from near 12 percent. So, the confidence was regained enough to discuss the debt rescheduling with the creditors [33]. However, the crisis did not go away until the late 1980 s due to the boring negotiations for a long time. In 1988 , currency crisis broke out again and the economy grew negatively for three years until 1990 .

This severe crisis called for the regime change. Carlos
Menem from the Peron Party came to power in 1991. He appointed Domingo Cavallo as the minister of economy. Cavallo advocated the 'new economic policy.' He enforced a tightening policy, adopted the fixed exchange rate system, reduced the number of civil servants and government agencies, and privatized most state-owned corporations with the 'small government policy'. Menem was called as a traitor from his supporters once for the opposite to the traditional policy of the Peron party.

However, the stabilization of prices saved the economy. What policy stabilized the prices? A monetary reform was carried out to lower 10,000 austral to 1 peso, and the exchange rate system that fixed 1 peso at 1 dollar was enforced. The current account surplus of $\$ 4.5$ billion in 1990 played a crucial role in the success of this policy. This amount was more than three times the international reserve in 1989. Its surplus rose to such a large scale thanks to the explosive rising of its exchange rate which rose by 41 times in 1989 and 12 times in 1990, increasing temporarily its international competitiveness. At last, the confidence on the new currency was created. The consumer prices, which had risen by 41 times in 1989 and by 24 times in 1990, fell to 2.7 times in 1991 and reached one digit in 1994 at last. As the prices stabilized, its production and export were promoted, and foreign investments were activated to boost the economy. Its growth rate was 10.5 percent in $1991,10.3$ percent in 1992, 6.3 percent in 1993 and 8.5 percent in 1994.

These high growth rates caused the economy to overheat, worsening its international payment balance. The deficit of current account exceeded $\$ 5$ billion in 1992 and continued to increase, reaching $\$ 11.2$ billion in 1994. At this time, a currency crisis broke out in Mexico, which infected the Argentine economy, resulting in its growth rate of -2.8 
percent in 1995. Such an economic cooling reduced greatly the deficit of international payment. So, the growth rate recovered to 8.1 percent in 1997 . In this process, a large increase in its fiscal spending caused the economy to overheat and deteriorated the international competitiveness again. The current account deficit increased to $\$ 11.2$ billion in 1997 , and larger in 1998 at $\$ 14.5$ billion. As the foreign exchange market became unstable, the Menem regime was busy to acquire foreign debts, which increased to $\$ 141.4$ billion in 1998 from slightly over $\$ 60$ billion in the early 1990s. The crisis broke out again in 1998. Its growth rate became negative from 1999 and its recession prolonged. In addition, a political turmoil occurred as corruption scandals sprang up with the income gap worsened.

Table 3. Major indicators of Argentina in 1988-1998 (\%, \$Billion)

\begin{tabular}{|c|c|c|c|c|c|c|c|c|c|c|}
\hline Year & 1989 & 1990 & 1991 & 1992 & 1993 & 1994 & 1995 & 1996 & 1997 & 1998 \\
\hline Prices Rate & 4,100 & 2,439 & 272 & 24.9 & 10.7 & 4.1 & 3.4 & 0.2 & 0.5 & 0.9 \\
\hline Growth Rate & -7.0 & -1.3 & 10.5 & 9.6 & 5.7 & 5.8 & -2.8 & 5.5 & 8.1 & 3.8 \\
\hline Current Acc. & -1.3 & 4.6 & -0.7 & -5.5 & -7.8 & -10.1 & -2.8 & -3.8 & -12.1 & -14.5 \\
\hline
\end{tabular}

Source; International Financial Statistics 2000, IMF

In 1999, Fernando de la Rua of the Radical Party was elected president. The unemployment rate soared to 16 percent as the recession was deepened. IMF provided bridge loans under the condition of austerity measures. But it did not calm down the crisis because of its huge foreign debts. As economic difficulties were resolved hardly, the public approval rate for de la Rua fell to 18 percent in early 2001. Ricardo L. Murphy, appointed as the minister of economy, pledged to cut the fiscal spending and to comply with the agreement with IMF and creditors [33]. However, the president reversed the situation by saying that he would not follow Murphy's opinion after talking with the former minister Cavallo who claimed to find a better solution.

Cavallo, who pushed Murphy out of the ministry, offered the creditors a bond swap which exchanged the debts due date with the long-term debts. His confidence at home and abroad was strong at the beginning because he had played a decisive role in overcoming the currency crisis in the early 1990s. However, the crisis was hardly settled though the bond swap was made. He suggested a new bond swap, but creditors refused it. He asked the IMF for bailout as its international reserve was depleting. But it was rejected too because creditors' trust was destroyed. As the situation worsened, capitals flew out and bank-runs happened. The streets were full of riots. At least 30 reported deaths [33].

On December 1, he introduced a measure to stop bank runs. It was called as the Corralito, little fence. This policy measure involved the freeze of bank accounts for 90 days, allowing only a small amount withdrawal each week and prohibiting the withdrawal in US dollar. The lack of cash availability worsened the recession and imposed serious hardships on the people, who took streets in protest. Cavallo was fired [33]. In December 2001, de la Lua resigned, and Adolfo Rodriguez Saa held office as acting president. But he could not save the economy despite creating a new currency and devaluating peso. In January 2002, Eduardo Duhalde of the Peron Party took office till May 2003. This new government declared the default on public debts. The negotiation for the debt repayment, begun in 2001, was concluded in 2005. According to the negotiation announced a few years later, investors recovered only $30 \%$ of their loans while 70 percent of foreign debts was forgiven.

As politics continued to confuse, the capital outflow became serious, its international reserve fell to $\$ 10.5$ billion at the end of 2002, resulting in a record low growth rate of 10.9 percent. Fortunately, this rapid recession brought the economy back to recover. The supplier's market was created by the faster decline of aggregate supply than aggregate demand, which improved the companies' balances to increase productions, employments and investments. And the economic downturn improved the current account by the surplus of $\$ 8.8$ billion in 2002 .

After Nestor Kirchner took office in May 2003, even its politics was stabilized. The economy began to grow in earnest. Its growth rate remained high every year since 2003 until the global crisis in 2008. Prices inflation also stabilized to a single digit, and its international reserve continued to increase. However, after Cristina Fernandez, Nestor's wife, came to power, the fiscal expansion for welfare got the economy to overheat, causing the international payment balance to deteriorate. Its exchange rate soared since the beginning of 2014, and a currency crisis broke out again. Argentina had to declare a partial moratorium in July.

Table 4. Growth Rate and Current Account of Argentina in the 2000s (\%, \$ billion).

\begin{tabular}{|c|c|c|c|c|c|c|c|c|c|c|c|c|}
\hline Year & 1999 & 2000 & 2001 & 2002 & 2003 & 2004 & 2005 & 2006 & 2007 & 2008 & 2009 & 2010 \\
\hline Growth Rate & -3.4 & -0.8 & -4.4 & -10.9 & 8.8 & 9.0 & 9.2 & 8.5 & 8.7 & 7.0 & 0.7 & 9.2 \\
\hline Current Acc. & -11.9 & -9.0 & -3.8 & 8.8 & 8.1 & 3.2 & 5.3 & 7.8 & 7.4 & 6.8 & 8.5 & 3.6 \\
\hline
\end{tabular}

Source; International Financial Statistics 2012, IMF

\subsection{Intersect Between Success and Failure; Mexico in 1981 and 1995}

Mexico confronted a currency crisis in 1981 that was infected by the Argentine crisis. USA and IMF stepped up to provide bailouts, but its government did not accept the condition. After a long negotiation, Mexico was exempted much of the principal of foreign debt, but its economic 
performance was the worst in its history. On the contrary, when the crisis broke out in end 1994, its government accepted immediately the condition and achieved a recovery that was unparalleled, comparing to the early 1980 s. Depending on how the government responded, the result was as big as heaven and earth. The former led to the so-called '10 years lost', while the latter resulted in a successful overcome against the crisis.

These two cases were good examples which needed to be examined in detail. The currency crisis in 1981 had hit the economy for a long time. Not only did the economy record negative growth rates for two years due to the crisis, but also the economic stagnation lasted for eight years until 1989. Even after the recovery, the crisis risk did not go away. On the contrary, the crisis in 1995 was overcome successfully thanks to proper policy prescriptions. Unfortunately, this outstanding achievement was not appreciated well by the concerned. Therefore, improper prescriptions were made against the crisis in 2001 like that in 1981, and the economy stagnated for 3 years. So, it is advisable to block the crisis in the early stage by seeking its root and enacting proper prescriptions on it.

First, just before the crisis in 1981, its economy was booming in the late 1970 s as the oil field was discovered in 1976. Its oil production increased from 40 thousand barrels in 1978 to 72 million barrels in 1981. Believing in this oil resource, its government invested much in construction of social overhead capital and industrialization. The funds for them were supplied by foreign debts. Its fiscal spending increased by annual average of 45 percent during 1978-1981. Its average growth rate had been 8-9 percent annually. However, it was a serious overheating. Consumer prices rose steadily, reaching 28 percent in 1981. This price rise deteriorated its international competitiveness. The deficit of current account reached $\$ 10.4$ billion in 1980 and $\$ 16.3$ billion in 1981, 6.5 percent of GDP [34]. This deficit was the root cause to deplete its international reserve.

Table 5. Mexico's Main Economic Indicators (\%) 1977-1983.

\begin{tabular}{llllllll}
\hline Year & $\mathbf{1 9 7 7}$ & $\mathbf{1 9 7 8}$ & $\mathbf{1 9 7 9}$ & $\mathbf{1 9 8 0}$ & $\mathbf{1 9 8 1}$ & $\mathbf{1 9 8 2}$ & $\mathbf{1 9 8 3}$ \\
\hline Growth rate & 3.4 & 8.3 & 9.2 & 8.3 & 7.9 & -0.6 & -4.2 \\
Prices rate & 29.1 & 17.5 & 18.2 & 26.3 & 27.9 & 75.0 & 92.9 \\
Current & -2.0 & -2.3 & -3.1 & -5.4 & -6.5 & -3.4 & 3.9 \\
Acc./GDP & & & & & & \\
\hline
\end{tabular}

Source; Current Status and Lessons of Financial Reform in Mexico, in Korean, Sun-Deok Jang, The Korea Institute for International Economic Policy, 1998

Though the overheat increased the deficit as above, there happened no currency crisis till late 1981. What was the reason? It was because the international market believed in its abundant oil reserve, oil production and its rising price. Mexico brought in foreign debt as much as needed. The debt increased to $\$ 75.3$ billion in 1981 from \$34 billion in 1978 . However, the oil price dropped to $\$ 28$ per barrel in 1982, and to $\$ 11.8$ in 1986 from $\$ 33$ in early 1981 [34]. Moreover, the interest burden on foreign debt soared since the base interest rate of the Fed in USA exceeded $20 \%$. Its government did not neglect this dangerous situation. In June 1981, the Portillo government announced some measures to cut its budget, to tighten import permits and to defend its exchange rate. But these measures were not enacted faithfully. For an instance, it announced $4 \%$ cut in fiscal budget, but increased by $18 \%$ which fueled the economic overheat further, increasing the deficit of international payment. Its exchange rate soared from 200 pesos in 1980 to 1,000 pesos per dollar in 1982. As a result, foreigners recovered their investments due to the foreign-exchange loss. And domestic firms hurried to pay off foreign debts, which caused the credit destruction. As its international payment reserve was depleting, its government asked the IMF for bailout.

The delegation of IMF visited Mexico three times in January, May and June 1982, but its government, facing the presidential election in December, opposed the IMF's austerity program. The negotiation between them stopped. Instead, the Mexican government signed a $\$ 600$ million of currency swap with the US Fed in April and received \$200 million in loan and $\$ 700$ million in debt repayment. However, the Treasury Secretary, Silvia Herzog, called Paul Volker of FRB governor, Donald Reagan of USA Treasury Secretary, and Jacques de Larosiere of IMF's governor to inform that the money received for currency swap ran out [33]. He declared a moratorium in August 1982.

Thanks to the negotiations with creditors, the maturity of $\$ 10$ billion in debt principal was extended to November 23 from August 23, and its government agreed to follow the IMF's austerity plan for receiving new funds. Nevertheless, the surge of its exchange rate was inevitable. It rose to 120 pesos per dollar from 26 pesos even after its currency was denominated, and it stabilized at 80 pesos per dollar. However, the president issued a new card in September when the program enacted in earnest, surprising creditors. He gave his last remarks to nationalize 49 banks and to control the exchange rate despite the presidential election in place and his lame-duck [33].

In November 1982, a meeting was held to discuss this situation in New York led by the IMF. Larosiere decided to resume the negotiation for bailout. Mexico had to pay $\$ 10$ billion of public debts in the following year, the short-term debt of $\$ 2.5$ billion provided by the BIS should be repaid, its current account deficit was $\$ 4.5$ billion in 1982 , and at least $\$ 1.5$ billion was needed to fill its international reserve. In short, debt adjustments worth $\$ 8.3$ billion were urgent [33]. The negotiation between Mexico and creditors reached rarely a deal for more than three years. Its economic recession accelerated, and the prices exploded. Its growth rate was -0.6 percent in 1982 and -4.2 percent in 1983, and the inflation rate rose to 75 percent and 93 percent respectively each year. The reckless persistence of its government led to this devastating situation. The government of Miguel de la Madrid, launched in December 1982, did not enter the negotiation with IMF until August 1985.

The Mexican economy showed some signs to recover as its international reserve was recovered by the IMF bailout. However, its government increased the fiscal expenditure for 
the municipal election. IMF stopped providing additional bailout. Its currency crisis rebounded in earnest and the economy recessed quickly. Its growth rate fell to -1.3 percent in 1986 and remained at $1 \%$ level for next two years. Its price inflation, which had stabilized little by little, soared again. A currency reform was made to resolve the inflation, while its exchange rate exploded from 0.19 peso in 1984 to 2.21 pesos per cent in 1987, escalating further the price inflation by 131 percent in 1987.

Table 6. Mexico's main economic indicators (\%, peso/cent) in 1984-1989.

\begin{tabular}{lllllll} 
Year & $\mathbf{1 9 8 4}$ & $\mathbf{1 9 8 5}$ & $\mathbf{1 9 8 6}$ & $\mathbf{1 9 8 7}$ & $\mathbf{1 9 8 8}$ & $\mathbf{1 9 8 9}$ \\
\hline Growth Rate & 3.3 & 2.6 & -1.3 & 1.8 & 1.2 & 3.3 \\
$\begin{array}{l}\text { Prices Rate } \\
\text { Exchange }\end{array}$ & 66.7 & 57.8 & 87.3 & 130.8 & 114.3 & 20.1 \\
Rate & 0.19 & 0.37 & 0.92 & 2.21 & 2.38 & 2.64 \\
\hline
\end{tabular}

Source; Current Status and Lessons of Financial Reform in Mexico, in Korean, Sun-Deok Jang, The Korea Institute for International Economic Policy, Seoul Korea, 1998

The new government of Carlos Salinas de Gortari, launched in 1988, enacted the Foreign Investment Promotion Act, opened greatly the industrial investment and financial market to foreigners, promoted market functions by massive deregulation, and reduced public corporations from 1,155 to 195 in late 1994. The tightening of fiscal spending was also carried out to stabilize the prices. Then the exchange rate was stabilized, and the growth rate became good, with an annual average of $3.5 \%$ during 1989-1994. The consumer prices rose by only 7.9 percent in 1994 . This performance was so incomparable to that of Argentina at that time. This policy should have been chosen early.

Table 7. Mexico's Main Economic Indicators (\%, peso/cent) in 1990-1995

\begin{tabular}{lllllll}
\hline Year & $\mathbf{1 9 9 0}$ & $\mathbf{1 9 9 1}$ & $\mathbf{1 9 9 2}$ & $\mathbf{1 9 9 3}$ & $\mathbf{1 9 9 4}$ & $\mathbf{1 9 9 5}$ \\
\hline Growth Rate & 4.4 & 3.6 & 2.1 & 2.0 & 4.5 & -6.2 \\
Prices Rate & 26.6 & 22.7 & 15.5 & 8.0 & 7.1 & 52.0 \\
$\begin{array}{l}\text { Exchange } \\
\text { Rate }\end{array}$ & 2.95 & 3.07 & 3.12 & 3.30 & 3.47 & 6.49 \\
\hline
\end{tabular}

Source; Current Status and Lessons of Financial Reform in Mexico, in Korean, Sun-Deok Jang, The Korea Institute for International Economic Policy, 1998

However, the long-run restraint on its exchange rate for the price stabilization weakened its international competitiveness, which deteriorated its international balance, creating a new currency crisis in late 1994. Despite the increase of foreign debt from $\$ 95.3$ billion in 1989 to $\$ 139.8$ billion in 1994 , the government expanded its fiscal spending ahead the presidential election, which caused the economy to overheat. So, its current account deficit increase to 7.9 percent of GDP in 1994. And the political situation became serious. There happened a peasant riot against the NAFTA in January, and the presidential candidate and secretary general of the ruling party were assassinated in March and September respectively. Then, foreign capitals outflew and domestic capitals escaped abroad [19].

The government of Ernesto Zedillo converted the exchange rate system to floating one from fixed one, and declared to privatize state corporations, to tighten fiscal spending, to improve the international payment balance, and to stabilize the prices inflation in December 1994. And the agreement was signed between workers, employers, farmers and the government to control the wage increase in January 1995. In response, the G7 Conference announced to support $\$ 52$ billion for Mexico in February 1995. The bailout negotiation with IMF was concluded soon. Though its growth rate was $-6.2 \%$ in 1995 due to the crisis and the inflation rate exceeded 30 percent during 1995-1996 due to the rise of its exchange rate, its growth rates increased soon, and the prices were stabilized gradually. Its exchange rate also stabilized after 1998. These performances were relatively good comparing to the 1980 s.

Table 8. Mexico's Main Economic Indicators (\%, peso/cent) in 1995-2000.

\begin{tabular}{lllllll}
\hline Year & $\mathbf{1 9 9 5}$ & $\mathbf{1 9 9 6}$ & $\mathbf{1 9 9 7}$ & $\mathbf{1 9 9 8}$ & $\mathbf{1 9 9 9}$ & $\mathbf{2 0 0 0}$ \\
\hline Growth Rate & -6.2 & 5.0 & 6.8 & 5.0 & 3.8 & 6.6 \\
Prices Rate & 35.0 & 34.4 & 20.6 & 15.9 & 16.6 & 9.5 \\
Current Acc. & -297 & -16 & -77 & -161 & -140 & -187 \\
\hline
\end{tabular}

Source; International Financial Statistics 2012, IMF

Unfortunately, the crisis broke out in Argentina in 2001 due to the fall of Nasdaq market and the September 11 attacks of terrorists in USA which worked the credit destruction principle in the world economy. The countries with large deficits in international payment were infected by the Argentine crisis. Mexico was no exception. Its current account deficit reached $\$ 16.7$ billion in 1998 , and more than $\$ 10$ billion annually until 2002, causing another currency crisis. The annual growth rate was 0 percent level in 2001 and 2002, and only 1.4 percent in 2003. This long-run economic stagnation caused the current account deficit to drop below $\$ 10$ billion after 2003 and to $\$ 4.5$ billion in 2006 . As the risk of currency crisis diminished, the Mexican economy continued to grow stable until the 2008 global financial crisis.

\subsection{Failure Caused by Confusion of Terms; Greek Case in the 2010s}

The Greek crisis was recognized by the public in May 2010 when it was announced that the European Central Bank (ECB) and the IMF provided $€ 110$ billion in bailout. However, the crisis was not settled for years until the late 2010s. This long-run crisis worsened the business balances of companies, and their investments and employments were long missing. Financial institutions such as banks also did not work well due to their worsening balances. So, the additional bailout of $\$ 86$ billion was concluded between the Greek government and the international creditors on August 11, 2015. Would the Greek crisis be settled? The answer to the question would not be positive. Since there had already been huge bailouts of $€ 250$ billion in two rounds, the third bailout would likely to fail in the end as the two bailouts did. What was the reason?

The most serious problem lied in the inaccurate diagnosis 
on its crisis. If it was so inaccurate, the policy prescription on it would be improper. The fact that Greece had received bailouts three times proved the wrong policy prescription based on its inaccurate diagnosis. Why was it inaccurate? The main reason was that the term of currency crisis was included in financial crisis. So, the crisis was often called as financial crisis. In the reality, the term of financial crisis is used for currency one, fiscal one and financial one. But these three crises have different causes and developing processes from each another, so they should be called separately; the first should be called as currency crisis, the second should be called fiscal crisis, and the third should be called financial crisis.

In this regard, the Greek crisis had already progressed under water since 2008. Its current account deficit reached 13.6 percent of its GDP in 2008, prompting currency crisis. As the deficit grew like this, it should have judged that its international reserve would deplete shortly. Of course, Greece, as a member of the EU, was able to withstand with the crisis in short term by the Euro that the ECB provided. However, its huge deficit of international payment meant that money was under pressure to flow-out abroad. The Greek economy was in danger to fall into ruin since money acted like blood of human body. Even its $10 \%$ leakage threatens the life. Despite the above fact, IMF and ECB claimed the improvement of its fiscal balance for the condition of bailout because the crisis was understood as a fiscal crisis. So, the crisis worsened even after three large bailouts.

If Greece was in a fiscal crisis, Spain had no reason to suffer economic hardships at that time. The Spanish finance was healthy until the crisis broke out in 2009. Its national debt ratio was less than even that of Germany, which proved its healthy finance. However, Spain has experienced a severe crisis, with unemployment rate exceeding $20 \%$ once. Spain also suffered a currency crisis, with its current account deficit reaching 9.6 percent of GDP in 2008. Fortunately, in 2009, the current account deficit fell sharply to 3.8 percent of GDP, which did not drive the Spanish economy into a serious situation like Greece. Greece's deficit decreased to 6.9 percent of GDP in 2009, but it was still too large.

\section{Conclusions and Further Considerations}

Identifying the cause of currency crisis is relatively easy. In almost countries which experienced the crisis, the followings happened in turn; economic overheating $\rightarrow$ import surge $\rightarrow$ deteriorating of international payment balance $\rightarrow$ recovering international reserve by foreign debt $\rightarrow$ surge of exchange rate $\rightarrow$ loss of foreign exchange $\rightarrow$ stop of foreign debt inflow and outflow of domestic capital $\rightarrow$ credit destruction $\rightarrow$ financial crisis $\rightarrow$ depletion of international reserve. In short, economic overheating is the root of currency crisis. Nevertheless, the root and its developing process are not yet well known in the reality. So, the currency crisis has repeated intermittently in many countries. If the root is not clarified well, the crisis would repeat in the future. This paper clarifies its developing process as well its root cause as seen above.

Regretfully, this paper covers only the currency crisis, while it is always accompanied by a financial crisis. So, it is necessary to research further the economic principle of financial crisis. Although Kindleberger clarified the general developing process of the financial crisis such as from Manias to Panics and Crashes, it is not yet clarified the scientific principle what causes inevitably Manias and why Panics and Crashes happen inevitably. This principle should be investigated in near future.

\section{References}

[1] Kaminsky, Graciela L. and Carmen M. Reinhart, The Twin Crises: the causes of banking and balance-of-payments problems, International Finance Discussion Papers 544, Board of Governors of the Federal Reserve System (U.S.) Washington DC, USA, 1999

[2] Kindleberger, Charles P., Manias, Panics, and Crashes, John Wiley \& Sons, 1978

[3] Burkart, Oliver and Virginie Coudert, "Leading indicators of currency crises for emerging countries," Emerging Markets Review, Volume 3, Issue 2, pp. 107-133, June 2002

[4] Candelon, Bertrand, Elena-Ivona Dumitrescu, and Christophe Hurlin, "Currency crisis early warning systems: Why they should be dynamic," International Journal of Forecasting, Volume 30, Issue 4, pp. 1016-1029, October-December 2014

[5] Franck, Raphael and Schmied, Aurelien, "Predicting Currency Crisis Contagion from East Asia to Russia and Brazil: An Artificial Neural Network Approach,” 2004, https://ssrn.com, Feb. 26, 2020

[6] Feng Yun and WU Chong-Feng, "Research on Currency Crisis Early Warning Systems," Systems Enging-theory Methodology Application, January 2002

[7] Goldstein, Morris \& Philip Turner, "Banking Crises in Emerging Economies: Origins and Policy Options," BIS Economic Papers NO. 46, October 1996

[8] Kaminsky, G., S. Lizondo and C. Reinhart, "Leading Indicators of Currency Crises," 1998, https://mpra.ub.unimuenchen.de/6981/1/MPRA_paper_6981.pdf, Jun 11, 2020

[9] Kaur, Inderjit, "Early Warning System of Currency Crisis: Insights from Global Financial Crisis 2008." Journal of Applied Economics; Hyderabad Vol. 14, Iss. 1, pp. 69-83, Jan 2015

[10] Kidman, Andrew, "Currency Crisis Early Warning Systems: Robust Adjustments to the Signal-Based Approach," 2010, http://duke.edu, February 21, 2020

[11] Krugman, P., "A model of balance-of-payments crisis," Journal of Money Credit and Banking, vol. 11, pp. 311-325, 1979.

[12] Lindgren, Carl-Johan, Gillian Garcia and Matthew I. Saal, Bank Soundness and Macroeconomic Policy, IMF, Washington DC, USA, 1996. 
[13] Nag, Ashok K. and Amit Mitra, "Neural Networks and Early Warning Indicators of Currency Crisis," Reserve Bank of India Occasional Papers, Vol. 20, No. 2, 1999

[14] Obstfeld, M., "Models of currency crisis with self-fulfilling features," NEBR Working Paper, no. 5285, European Economic Review, 1995

[15] Sevim, Cuneyt, Asil Oztekin, Ozkan Bali, Serkan Gumus, and Erkam Guresen, "Developing an early warning system to predict currency crises," European Journal of Operational Research, Volume 237, Issue 3, pp. 1095-1104, 16 September 2014

[16] Krugman, Paul and Jeremy Khan, "Saving Asia", Fortune, September 7, 1998

[17] Flood, R. and P. Garber, "Collapsing exchange-rate regimes: Some linear examples," Journal of International Economics Volume 17, Issues 1-2, August 1984, Pages 1-13

[18] Feldstein, Martin, "Refocusing the IMF," Foreign Affairs, Volume 77 No. 2, March/April 1998

[19] Kim, David Deok - Ki and Jung - Soo Seo, "Does FDI inflow crowd out domestic investment in Korea?", Journal of Economic Studies, Vol. 30 No. 6, pp. 605-622, December 2003

[20] Glicka, Reuven and Andrew K. Rose, "Contagion and trade: Why are currency crises regional?", Journal of International Money and Finance, Volume 18, Issue 4, pp. 603-617, August 1999

[21] Khan, Saleheen and Kwang Woo "Contagion in the stock markets: The Asian financial crisis revisited," Journal of Asian Economics, Volume 20, Issue 5, pp. 561-569, September 2009

[22] Borensztein, Eduardo and Jong-Wha Lee, "Financial crisis and credit crunch in Korea: evidence from firm-level data", Journal of Monetary Economics, Volume 49, Issue 4, pp. 853875, May 2002

[23] Burnside, Craig, Martin Eichenbaum, and Sergio Rebelo, "Prospective Deficits and the Asian Currency Crisis," Journal of Political Economy, Volume 128, Number 2, February 2020
[24] Choi, Doo-Yull and Yeonho Lee, "Financial Supervision of Merchant Banking Corporations as a Cause of Korea's Currency Crisis," The Journal of the Korean Economy, Vol. 7, No. 1 pp. $77-118$, Spring 2006

[25] Corsetti, Giancarlo, Paolo Rosenti and Nouriel Roubini, "What caused the Asian currency and financial crisis?", Japan and the World Economy, Volume 11, Issue 3, pp. 305-373, October 1999

[26] Johnson, Simon, Peter Boone, Alasdair Breach and Eric Friedman, "Corporate governance in the Asian financial crisis", Journal of Financial Economics, Volume 58, Issues 12, pp. 141-186, 2000

[27] Mitton, Todd, "A cross-firm analysis of the impact of corporate governance on the East Asian financial crisis", Journal of Financial Economics, Volume 64, Issue 2, pp. 215241, May 2002

[28] Erkens, David H., Mingyi Hung and Pedro Matos, "Corporate governance in the 2007-2008 financial crisis: Evidence from financial institutions worldwide", Journal of Corporate Finance, Volume 18, Issue 2, pp. 389-411, April 2012

[29] Aebi, Vincent, Gabriele Sabato and Markus Schmid, "Risk management, corporate governance, and bank performance in the financial crisis", Journal of Banking \& Finance, Volume 36, Issue 12, pp. 3213-3226, December 2012

[30] Chang, Ha-Joon, "Korea: The misunderstood crisis," World Development, Volume 26, Issue 8, pp. 1555-1561, August 1998

[31] Sachs, Jeffrey, "The IMF and the Asian Flu," The American Prospect, Mar./Apr. 1998

[32] Stiglitz, Joseph, "10 Years After the Asian Crisis, We're Not Out of the Woods Yet," Project Syndicate, July 2007.

[33] Rhodes, William R., Banker to the World: Leadership Lessons from the Front Lines of Global Finance, McGraw-Hill, 2011.

[34] Jang, Sun-Deok, "Current Status and Lessons of Financial Reform in Mexico" in Korean, The Korea Institute for International Economic Policy, 1998 